\title{
Disease Severity Scores and Haemogram Parameters in Nigerian Sickle Cell Disease Patients
}

Emmanuel Okocha ${ }^{1}$, Emmanuel Onwubuya ${ }^{2}$, Charles Osuji ${ }^{2}$, Gladys Ahaneku ${ }^{2}$, Uche Okonkwo ${ }^{3}$, Nancy Ibeh ${ }^{4}$, John Aneke ${ }^{1^{*}}$, Ebele $\mathrm{Nwachukwu}^{5}$ and Christian Onah ${ }^{5}$

${ }^{1}$ Department of Haematology, Nnamdi Azikiwe University Teaching Hospital, Nnewi, Nigeria

${ }^{2}$ Department of Medicine, Nnamdi Azikiwe University Teaching Hospital, Nnewi, Nigeria

${ }^{3}$ Department of Medicine, University of Calabar, Cross River State, Nigeria

${ }^{4}$ Department of Medical Laboratory Science, Nnamdi Azikiwe University, Nnewi, Anambra State, Nigeria

${ }^{5}$ Department of Chemical Pathology, Nnamdi Azikiwe University Teaching Hospital, Nnewi, Nigeria

*Corresponding author: Dr. Aneke John C, Department of Hematology and Blood Transfusion, Nnamdi Azikiwe University Teaching Hospital, PMB 5025, Nnewi, Anambra State, Nigeria, Tel: +2348063756285; E-mail: anekejc@ymail.com

Received date: Oct 19, 2015, Accepted date: Dec 09, 2015, Publication date: Dec 14, 2015

Copyright: ( 2015 Okocha E, et al. This is an open-access article distributed under the terms of the Creative Commons Attribution License, which permits unrestricted use, distribution, and reproduction in any medium, provided the original author and source are credited.

\section{Abstract}

Background: Sickle cell disease (SCD) is associated with high mortality in Nigeria and the rest of sub-Saharan Africa; there is need to find easily available parameters that could predict disease severity and influence therapy.

Objective: To evaluate the haemogram of a population of SCD patients and correlate these with objective scores of disease severity.

Methods: Sixty (60) asymptomatic steady state (ASS) SCD patients in our clinic were randomly selected and interviewed with a questionnaire. Their haemogram was done using a 17 parameter, 3-part white cell differential, auto-analyser (KX 21N, Sysmex corporation, Chuo ku, Kobe, Japan) and objective severity scores calculated using a modification of the method proposed by Anyeagbu et al. Statistical analysis of data was done using Statistical Package for Social Sciences software, version 20 (SPSS Inc., IL, Chicago, USA), with significance assigned to $p$ values less than 0.05 .

Result: Of the 60 subjects assessed, severity scores were calculated for 49 : $11(22.4 \%), 31(63.3 \%)$ and 7 $(14.3 \%)$ met the criteria for mild, moderate and severe disease respectively. The haemogram parameters that were significantly positively correlated with disease severity were mean corpuscular haemoglobin concentration (MCHC), and white blood cell count (WBC), $\mathrm{p}=0.014$, and 0.001 respectively. Haemoglobin concentration $(\mathrm{Hb})$ and packed cell volume (PCV) were negatively correlated with disease severity $(p=0.001)$.

Conclusion: In addition to already known haemogram parameters that affect SCD severity (such as WBC, Hb concentration, and $\mathrm{PCV}$ ) $\mathrm{MCHC}$ also does same and can be manipulated by drugs and other kinds of therapy to ameliorate severity in patients.

Keywords: Sickle cell disease; Disease severity; Blood counts; Mean corpuscular haemoglobin concentration

\section{Introduction}

SCD is a disorder that presents with a wide variation of clinical features and is mostly found in developing countries where medical resources are scarce and the people mostly poor [1,2]. As a result of a number of factors, ranging from infrastructural deficits to a dearth of adequately trained manpower, the mortrality from SCD remains high in Nigeria and sub-Saharan Africa [3,4]. A number of factors including disease severity have been reported to influence the pattern of disease presentation, prognosis and survival; patients with severe disease tend to present with more complications and end-organ dysfunction $[5,6]$. The impact of end organ dysfunction in patients with sickle cell disease is particularly huge and is known to adversely influence disease manifestations and survival [7-9].
Recent studies has focused on evaluating ways of predicting and appropriately stratifying patients based on disease severity, with a view to identifying those that could benefit from more intense monitoring and treatment [10-12]. The observation that SCD patients (particularly children) with raised cerebral blood flow (through transcranial doppler ultrasonography) have increased risk of cerebrovascular disease has necessitated appropriate preventive treatment modifications for these group of patients with very encouraging results $[10,11]$.

Similarly, patients indentified as having severe SCD are currently offered hydroxycarbamide (and even stem cell transplantation) with significant impact on disease prognosis [12]. In an earlier study by Okocha et al. C-reactive protein (CRP) was identified as a surrogate marker of disease severity in Nigerian patients with SCD, hence its monitoring could guide appropriate patient stratification and therapy [13]. Interesting as this observation could be however, laboratory evaluation for CRP is presently not universally available in most health care facilities in resource poor settings such as Nigeria and this may 
also be the case in health institutions in the rest of sub-Saharan Africa. This therefore added more impetus to the search for a more universally available, cost effective surrogate marker of disease severity in this group of patients.

The aim of this study was therefore to correlate haemogram parameters with objectives scores of disease severity in Nigerian patients with SCD, with a view to finding cheap and universally available indices which could assist physicians in predicting severity/ outcome, thereby engendering appropriate treatment modification for patients, especially in resource poor settings.

\section{Subjects and Methods}

\section{Patient selection}

Sixty (60) asymptomatic steady state (ASS) sickle cell disease (SCD) patients; 37 males and 23 females were randomly selected from our paediatric, adult and out-station clinics. ASS in our patients was defined as those who had not in the last two weeks suffered any form of crisis, had a febrile illness and not transfused in the last 3 months.

The patients or their care givers were interviewed with a questionnaire which noted at what age the patient was diagnosed, past medical history including complications such as stroke, leg ulcers, avascular necrosis of the femoral or other bones and any other condition complicating the disease. Age, sex and other demographic data were also noted. Most of the subjects were on routine drugs such as folic acid, low dose soluble Aspirin, prophylactic antimalarial drugs and omega 3 fatty acids. Ethical approval was obtained from the hospital ethical committee.

\section{Disease severity}

An objective score was calculated for disease severity by using a modification of the method proposed by Hedo et al. [14]. Scores were assigned to the following parameters: patient white blood cell count, heamoglobin levels, and number of complications suffered from. Scores of $\leq 3$ were deemed mild disease. Scores of $3 \geq 5$ were considered moderate disease, while scores $>5$ were taken for severe disease.

\section{Sample collection and laboratory analysis}

Five (5) mls of blood was collected into Ethylene Diamine Tetra Acetic acid (EDTA) containers for full blood count (FBC) analysis. Analysis was done using a 17 parameter, 3-part WBC Deferential, Automated Hematology analyser (KX-21N, Sysmex Corporation, Chuo-ku, Kobe, Japan). Parameters done included packed cell volume (PCV), haemoglobin concentration, white blood cell count (WBC) and differentials, platelet count and red cell indices- mean corpuscular volume $(\mathrm{MCH})$, mean corpuscular haemoglobin $(\mathrm{MCH})$, and mean corpuscular haemoglobin concentration (MCHC).

\section{Statistical analysis}

Analysis of data was done using Statistical Package for Social Sciences software package version 20 (SPSS Inc., IL, Chicago, USA). Percentages, means and standard errors of mean were used to express the data obtained which were tabulated by sex, age, and other parameters that were analysed. $\mathrm{P}$ values were generated by comparing frequencies using Chi Square. Correlation between variables was determined using Spearman's or Pearson's correlation tests. Significance was assigned to $\mathrm{p}$ values less than 0.05 .

\section{Results}

The mean and median ages for the subjects were $20.9 \pm 10.23$ and 20 years (range of 4-47 years) respectively. There was no significant statistical difference in the ages of male and female study subjects $(\mathrm{p}=0.3$, Table 1$)$.

Table 2 shows the mean and median haemogram values for the subjects. Of the 60 subjects assessed, severity scores were calculated for 49 of them; $11(22.4 \%) 31(63.3 \%)$ and $7(14.3 \%)$ met the criteria for mild, moderate and severe disease respectively. Table 3 shows the correlation between haemogram values and disease severity. The haemogram parameters that were significantly positively correlated with disease severity were MCHC, MCV and WBC ( $p$ values $=0.014$, 0.025 and 0.001 respectively). Haemoglobin concentration $(\mathrm{Hb})$ and PCV were negatively correlated with disease severity $(p=0.001)$.

Table 4 shows a comparison of various haemogram parameters across different categories of disease severity, $\mathrm{Hb}, \mathrm{WBC}$ and PCV remained significant ( $\mathrm{p}=0.001$, respectively); while $\mathrm{MCHC}$ was close to significance $(p=0.096)$. Figures 1-3 are graphical representations of the relationship between disease severity score and $\mathrm{WBC}, \mathrm{Hb}$ and PCV respectively in study subjects.

\begin{tabular}{|l|l|l|l|l|l|}
\hline Parameters & N & Mean & Standard Deviation & Median & P-value \\
\cline { 1 - 5 } Age & 60 & 20.86 & 10.23 & 20 & \\
\cline { 1 - 3 } & 23 & 22.68 & 8.09 & 18 & \multirow{2}{*}{0.297} \\
\cline { 1 - 3 } & 37 & 19.78 & 11.28 & 11.5 & \\
\cline { 1 - 4 } & & & & &
\end{tabular}

Table 1: Age and Sex distribution of Subjects.

\begin{tabular}{|l|l|l|l|l|}
\hline Parameters & N & Mean & Standard Deviation & Median \\
\hline PCV & 60 & 0.23 & 0.05 & 0.23 \\
\hline HB & 60 & 7.37 & 1.74 & 7.2 \\
\hline WBC & 60 & 12.72 & 5.18 & 11.6 \\
\hline RBC & 60 & 2.79 & 0.73 & 2.74 \\
\hline Platelet & 60 & 327.08 & 133.37 & 338 \\
\hline MCV & 60 & 86.48 & 9.13 & 86.35 \\
\hline MCHC & 60 & 31.71 & 2.29 & 31.7 \\
\hline MCH & 60 & 27.44 & 3.23 & 26.7 \\
\hline
\end{tabular}

Table 2: Mean and Median values of Haematological Parameters of subjects. 
Citation: Okocha E, Onwubuya E, Osuji C, Ahaneku G, Okonkwo U, et al. (2015) Disease Severity Scores and Haemogram Parameters in Nigerian Sickle Cell Disease Patients. J Blood Disord Transfus 6: 324. doi:10.4172/2155-9864.1000324

Page 3 of 5

\begin{tabular}{|l|l|l|}
\hline Parameters & Pearson's correlation & P-Value \\
\hline Severity score vs MCH & -0.025 & 0.885 \\
\hline Severity score vs MCV & 0.289 & 0.025 \\
\hline Severity score vs MCHC & 0.315 & 0.014 \\
\hline Severity score vs RBC & 0.141 & 0.284 \\
\hline Severity score vs Platelet & 0.154 & 0.241 \\
\hline Severity score vs PCV & -0.554 & ${ }^{*} 0.001$ \\
\hline Severity score vs HB & -0.714 & ${ }^{*} 0.001$ \\
\hline Severity score vs WBC & 0.631 & ${ }^{*} 0.001$ \\
\hline "significant p-values. & & \\
\hline
\end{tabular}

Table 3: Correlation of severity score with some haematological parameters.

\begin{tabular}{|l|l|l|l|}
\hline Parameters & Mild disease & Moderate disease & Severe disease \\
\hline RBC & $1.63 \pm 0.314$ & $1.62 \pm 0.27$ & $2.01 \pm 0.40$ \\
\hline Platelet & $243.97 \pm 191.90$ & $253.94 \pm 187.48$ & $222.71 \pm 152.55$ \\
\hline PCV & $0.26 \pm 0.05$ & $0.20 \pm 0.04$ & $0.19 \pm 0.04$ \\
\hline HB & $8.9 \pm 1.49$ & $6.60 \pm 1.02$ & $6.04 \pm 1.35$ \\
\hline WBC & $7.11 \pm 5.63$ & $14.15 \pm 3.48$ & $17.54 \pm 7.35$ \\
\hline MCV & $86.43 \pm 8.86$ & $87.78 \pm 7.78$ & 83.001 \\
\hline MCH & $28.24 \pm 3.28$ & $26.94 \pm 2.94$ & 26.001 \\
\hline MCHC & $32.55 \pm 2.16$ & $30.77 \pm 2.29$ & 0.632 \\
\hline${ }^{*}$ significant p-values. & & & 0.422 \\
\hline
\end{tabular}

Table 4: Comparison of different haematological parameters by disease severities.

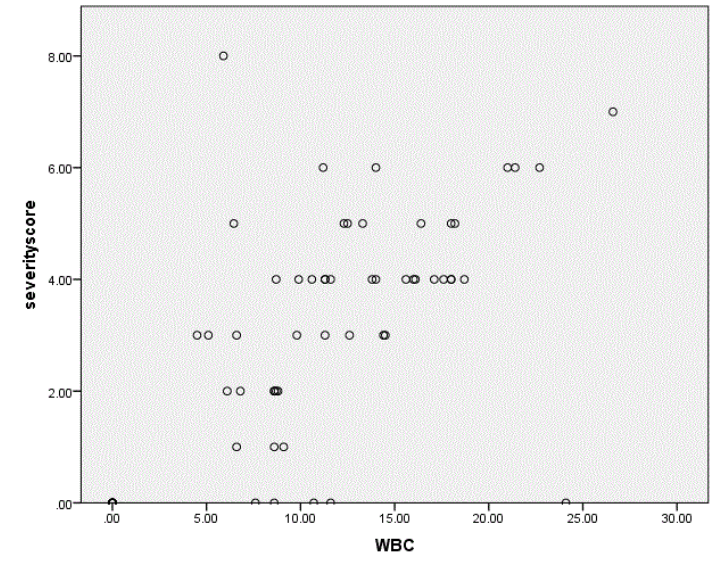

Figure 1: Association between white blood cell count (WBC) and severity score.

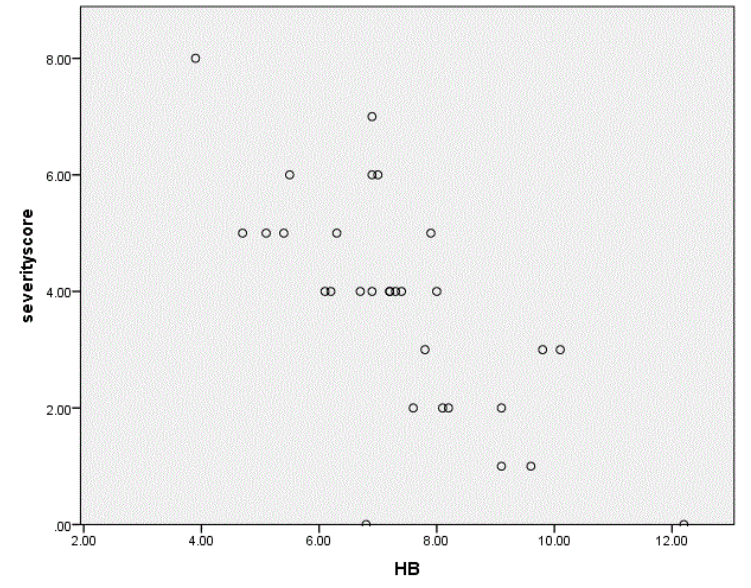

Figure 2: Association between Haemoglobin (HB) levels and severity score. 


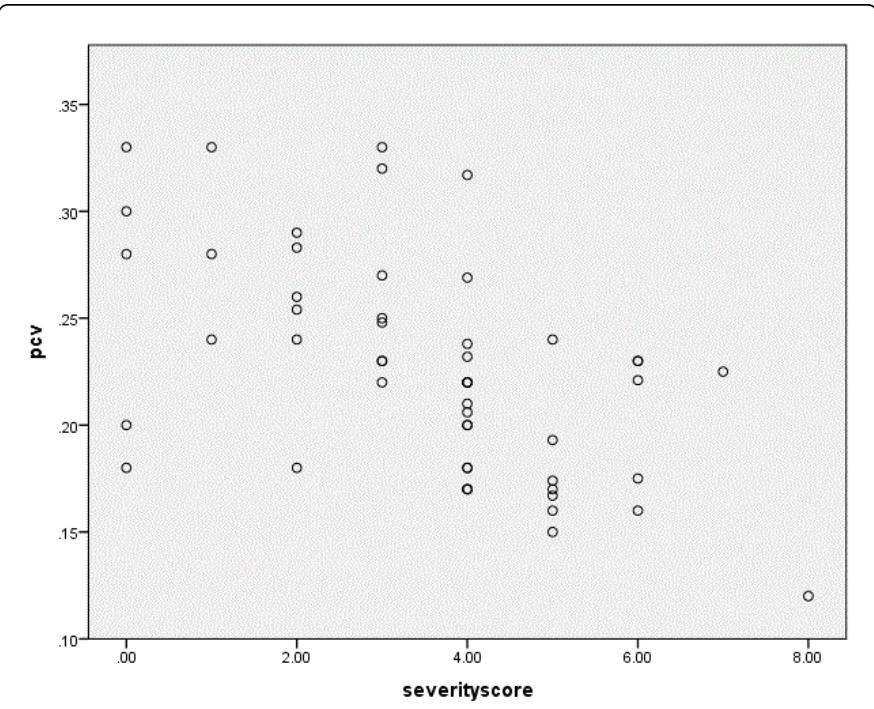

Figure 3: Association between PCV and severity score.

\section{Discussion}

SCD is a disease entity that is caused by a point mutation at the sixth position of the $\beta$ haemoglobin chain; causing glutamine to be replaced by valine in this position. This disorder is quite heterogeneous, with marked variations in both disease manifestation and clinical severity. Though many theories have been advanced to explain these variations, none has satisfactorily done so. In this work, an objective severity score was calculated and correlated with haemogram indices. Interestingly, after applying statistical methods, we observed that PCV, Hb, WBC and MCHC significantly correlated with disease severity (Tables 3 and 4). These findings are exciting because these parameters are available in most laboratories especially in developing countries (including Nigeria and the rest of sub-Saharan Africa) which have the highest burden of SCD.

$\mathrm{MCHC}$ is the amount of haemoglobin present per unit volume of packed red cells. It has been observed that low MCHC tends to be associated with an increase in deformability of red blood cells while higher values correlated with increased rigidity (less deformability). [15] More so, an increasing body of evidence has shown that overt iron deficiency in SCD appears to ameliorate disease severity [16,17]. In the light of the above, a number of workers have thus hypothesized that this observed clinical benefit may result from a decrease in MCHC with increased red cell deformability and whole blood rheology $[18,19]$. This phenomenon can be explained firstly, by understanding that when $\mathrm{Hb} \mathrm{S}$ is deoxygenated, there is some delay before polymerization begins. This is called the delay time and it has been shown to be directly proportional to $10^{\times 30}$ of the intracellular $\mathrm{Hb}$ concentration [20], therefore small decreases of MCHC can appreciable increase delay time; such that it may become less than capillary transit time. This will prevent polymerization, sickling, membrane damage and subsequently reduce haemolysis and therefore ameliorate severity. Intravascular red cell sickling with subsequent cell membrane damage (leading to sickle vasculopathy) and haemolysis are established pathways to sickle cell related end organ damage and thus have significant influence on disease severity and patient survival $[21,22]$.
In addition, evidence exists to show that in SCD, erythrocytic Hb-S concentration reduces the oxygen affinity of the blood thereby increasing the release of oxygen to end tissues [23]. Correspondingly, it has also been found that as MCHC increases, blood $\mathrm{O}_{2}$ affinity decreases with increased tendency for red cell sickling [24]. May et al. argued that this phenomenon may be due to the fact that high MCHC levels encourage polymerization of sickle haemoglobin (which is an initiating step in red cell sickling) [25]. Hydroxyurea is well known for its effect in ameliorating the clinical presentation of SCD and one of the mechanisms by which this comes about is by reducing the MCHC [26]. Therefore, the identification of the $\mathrm{MCHC}$ as a surrogate marker of disease severity in this study is not surprising, in view of its established influences on red cell deformability, haemoglobin $\mathrm{S}$ polymerization and tendency to sickling.

Packed cell volume, $\mathrm{Hb}$ concentration and $\mathrm{WBC}$ are well known parameters that affect severity in SCD [27-29]. Hence we used $\mathrm{Hb}$ concentration and WBC as parameters in our calculation of an objective severity score.

\section{Limitation of the study}

This work is limited by the fact that some of the data we collected were based on recall of our patients or their care givers, more so, a larger study size population could have given the work more power to detect significant results.

\section{Conclusion}

In addition to well known haemogram parameters such as WBC, $\mathrm{Hb}$ concentration, and $\mathrm{PCV}$, this work clearly shows that $\mathrm{MCHC}$ equally affects severity in SCD. The MCHC is measured by most automated heamatology analysers and it could equally be calculated manually, using the $\mathrm{Hb}$ concentration and PCV. This makes it available to physicians and other health professionals who care for patients with SCD, even in resource poor settings. Importantly, the MCHC is amenable to manipulation by drugs and other kinds of therapies and this could potentially be explored with a view to ameliorating disease severity in patients with SCD.

\section{References}

1. Chies JAB, Nardi NB (2001) Sickle cell disease: a chronic inflammatory condition. Medical hypotheses 57: 46-50.

2. Akinyanju OO (1989) A profile of sickle cell disease in Nigeria. Ann N Y Acad Sci 565: 126-136.

3. Piel FB, Patil AP, Howes RE, Nyangiri OA, Gething PW, et al. (2013) Global epidemiology of Sickle haemoglobin in neonates: a contemporary geostatistical model-based map and population estimates. Lancet 381:142-151.

4. Adewoyin AS (2015) Management of sickle cell disease: a review for physician education in Nigeria (sub-saharan Africa). Anemia 2015: 791498.

5. Serjeant GR (1995) Natural history and determinants of clinical severity of sickle cell disease. Curr Opin Hematol 2: 103-108.

6. Mpalampa L, Ndugwa CM, Ddungu H, Idro R (2012) Foetal haemoglobin and disease severity in sickle cell anaemia patients in Kampala, Uganda. BMC Blood Disorders 12: 11.

7. Powars DR, Elliott-Mills DD, Chan L, Niland J, Hiti AL, et al. (1991) Chronic renal failure in sickle cell disease: risk factors, clinical course, and mortality. Ann Intern Med 115: 614-620. 
Citation: Okocha E, Onwubuya E, Osuji C, Ahaneku G, Okonkwo U, et al. (2015) Disease Severity Scores and Haemogram Parameters in Nigerian Sickle Cell Disease Patients. J Blood Disord Transfus 6: 324. doi:10.4172/2155-9864.1000324

Page 5 of 5

8. Aneke JC, Adegoke AO, Oyekunle AA, Osho PO, Sanusi AA, et al. (2014) Degrees of kidney disease in nigerian adults with sickle-cell disease. Med Princ Pract 23: 271-274

9. Aneke JC, Adegoke AO, Oyekunle AA, Osho PO, Sanusi AA, et al. (2014) Haematological and clinical profile in Nigerian sickle cell disease patients with and without chronic kidney disease. Orient Journal of Medicine 26: 88-93.

10. Adams RJ, McKie VC, Hsu L, Files B, Vichinsky E, et al. (1998) Prevention of a first stroke by transfusions in children with sickle cell anemia and abnormal results on transcranial Doppler ultrasonography. N Engl J Med 339: 5-11.

11. Platt OS (2005) Preventing stroke in sickle cell anemia. N Engl J Med 353: 2743-2745.

12. Ferster A, Tahriri P, Vermylen C, Sturbois G, Corazza F, et al. (2001) Five years of experience with hydroxyurea in children and young adults with sickle cell disease. Blood 97: 3628-3632.

13. Okocha C, Manafa P, Ozomba J, Ulasi T, Chukwuma G, et al. (2014) Creactive Protein and Disease Outcome in Nigerian Sickle Cell Disease Patients. Ann Med Health Sci Res 4: 701-705.

14. Hedo CC, Aken'ova YA, Okpala IE, Durojaiye AO, Salimonu LS (1993) Acute phase reactants and severity of homozygous sickle cell disease. J Intern Med 233: 467-470.

15. Tempelhoff GV,, Schelkunov O,, Demirhan A, et al. (2015) Correlation between blood rheological properties and red blood cell Indices $(\mathrm{MCH}$, MCV, MCHC) in healthy women. Clin Hemorheol Microcirc.

16. Castro O, Poillon WN, Finke H, Massac E (1994) Improvement of sickle cell anemia by iron-limited erythropoiesis. Am J Hematol 47: 74-81.

17. Bouchair N, Manigne P, Kanfer A, Raphalen P, de Montalembert M, et al (2000) [Prevention of sickle cell crises with multiple phlebotomies]. Arch Pediatr 7: 249-255.

18. Lincoln TL, Aroesty J, Morrison P (1973) Iron-deficiency anemia and sickle-cell disease: a hypothesis. Lancet 2: 260-261.
19. Haddy TB, Castro O (1982) Overt iron deficiency in sickle cell disease. Arch Intern Med 142: 1621-1624.

20. Koduri PR (2003) Iron in sickle cell disease: a review why less is better. Am J Hematol 73: 59-63.

21. Detterich JA, Kato RM, Rabai M, Meiselman HJ, Coates TD, et al. (2015) Chronic transfusion therapy improves but does not normalize systemic and pulmonary vasculopathy in sickle cell disease. Blood 126: 703-710.

22. Sopko NA, Matsui H, Hannan JL, Berkowitz D, Champion HC, et al. (2015) Subacute Hemolysis in Sickle Cell Mice Causes Priapism Secondary to NO Imbalance and PDE5 Dysregulation. J Sex Med 12: 1878-1885.

23. Safo MK, Kato GJ (2014) Therapeutic strategies to alter the oxygen affinity of sickle hemoglobin. Hematol Oncol Clin North Am 28: 217-231.

24. Seakins M, Gibbs WN, Milner PF, Bertles JF (1973) Erythrocyte Hb-S concentration. An important factor in the low oxygen affinity of blood in sickle cell anemia. J Clin Invest 52: 422-432.

25. May A, Huehns ER (1975) The concentration dependence of the oxygen affinity of haemoglobin S. Br J Haematol 30: 317-335.

26. Ballas SK, Dover GJ, Charache S (1989) Effect of hydroxyurea on the rheological properties of sickle erythrocytes in vivo. Am J Hematol 32: 104-111.

27. Emmanuelchide O, Charle O, Uchenna O (2011) Hematological parameters in association with outcomes in sickle cell anemia patients. Indian J Med Sci 65: 393-398.

28. Phillips G Jr, Coffey B, Tran-Son-Tay R, Kinney TR, Orringer EP, et al. (1991) Relationship of clinical severity to packed cell rheology in sickle cell anemia. Blood 78: 2735-2739.

29. Okpala I (2004) The intriguing contribution of white blood cells to sickle cell disease-a red cell disorder. Blood reviews 18: 65-73. 